\title{
CULTURE EXPERIMENTS WITH A FRESHWATER CLADOCERAN, CERIODAPHNIA QUADRANGULA (O. F. MÜLLER, 1785), AS SUITABLE LIVE FOOD FOR MAYAN CICHLID (CICHLASOMA UROPHTHALMUS GÜNTHER 1862) LARVAE
}

\author{
O. FARHADIAN*, M. H. KHANJANI, Y. KEIVANY \& E. EBRAHIMI DORCHE \\ Department of Natural Resources, Isfahan University of Technology, Isfahan 84156-83111, Iran \\ *Corresponding author: omfarhad@cc.iut.ac.ir; farhadyo@yahoo.com
}

\begin{abstract}
Farhadian, O.; Khanjani, M. H.; Keivany, Y. \& Dorche, E. Ebrahimi 2012. Culture experiments with a freshwater cladoceran, Ceriodaphnia quadrangula (O. F. Müller, 1785), as suitable live food for mayan cichlid (Cichlasoma urophthalmus Günther 1862) larvae. Braz. J. Aquat. Sci. Technol. 16(2): 1-11. elSSN 1983-9057. Effects of five different diets of green microalgae, Scenedesmus quadricauda (S), poultry manure (P), cattle manure (C), and two mixed diet of $P+C(P C)$ and $S+P+C(S P C)$; and interaction effects of water temperature $\left(20,25,30^{\circ} \mathrm{C}\right)$ and photoperiod $(24: 0$, $0: 24$, and 12:12, hours light: hours dark) on production and growth of Ceriodaphnia quadrangula were examined separately. Then, mass cultivation of $C$. quadrangula and its application for rearing of an ornamental fish larva, Mayan cichlid (Cichlasoma urophthalmus) were carried out. Results showed that mean population density and specific growth rate (SGR) of C. quadrangula obtained $0.15-3.70$ ind. $\mathrm{mL}^{-1}\left(150-3700\right.$ ind. $\left.\mathrm{mL}^{-1}\right)$ and 0.019-0.18 day ${ }^{-1}$, respectively, maximum with $S$ diet and minimum with $C$ diet. The better mean population density and $S G R$ for $C$. quadrangula determined at interactions $25^{\circ} \mathrm{C}$ with $24: 0$ and $12: 12$, L:D, respectively, which was significantly higher than that at interactions $20^{\circ} \mathrm{C}$ and $30^{\circ} \mathrm{C}$. Nutritional analyses showed that protein and lipid contents of C. quadrangula were $54 \%$ and $12.3 \%$ dry weight, respectively. The fatty acid contents of $C$. quadrangula were $27.3 \%$ and $63.7 \%$ of saturated and unsaturated fatty acids, respectively. Among PUFAs (Polyunsaturated Fatty Acids) content, 18:2n-6 and 18:3n-3 were in highest level. Early cichlid larvae (5-weeks-old, $15.8 \mathrm{~mm}$ length and $110 \mathrm{mg}$ weight) and advanced larvae (10-weeks-old, $25.6 \mathrm{~mm}$ length and 240 mg weight) consumed C. quadrangula at range 220-584 ind. day ${ }^{-1}$ larvae ${ }^{-1}$ and 528-1956 ind. day ${ }^{-1}$ larvae ${ }^{-1}$, respectively, as well as suitable growth and survival rate. This study demonstrated that $C$. quadrangula could be used as live feed purposes for larval rearing in aquaculture.
\end{abstract}

Keywords: Freshwater zooplankton, diet, temperature and photoperiod, fatty acid, Mayan cichlid larvae, ornamental fish larvae, ingestion rate

\section{INTRODUCTION}

Cladocerans are small zooplanktonic crustaceans which almost exclusively live in freshwater. They are suitable live food sources used in aquaculture industry due to their abundance, tolerance to environmental conditions, high nutritional quality, ease of handling and sorting from other zooplanktons, suitable sizes $(0.2-6 \mathrm{~mm})$, parthenogenetic reproduction, short generation time, richness in digestive enzymes, and high caloric value (Nandini \& Sarma, 2003; Kumar et al., 2005).

Most early fish larvae consume rotifers in large amount and they need larger prey such as Moina and Ceriodaphnia with increasing age and size of the fish larvae (Khadka \& Rao 1986; Domínguez-Domínguez et al., 2002). For instance, larvae of angel fish preferred cladoceran (Nandini \& Sarma, 2000) and 5-week-old larvae of red eyed tetra (Moenkhausia sanctaefilomenae Steindachner) hardly consumed Moina macrocopa Straus and Ceriodaphnia dubia Richard (Alanis et al., 2009).

Determination of suitable culture requirements for cladocerans is very important and practical for its mass cultivation, such as food quantity and quality, water temperature, and photoperiod control growth and reproduction in cladoceran species (Boersma \& Vijverberg 1996; Nandini \& Sarma, 2000; AlvaMartinez et al., 2004). In this regard, sometimes light becomes a more important factor than temperature because it is the main stimulus for the periodic activity of many crustaceans (Jansson \& Kallander 1984), inhibits growth, maturation and reproduction of aquatic invertebrates (Miliou, 1992), and increased feeding activities (Buikema, 1973). According to Segal (1970), reproductive activities are light dependent and appear to be mediated by photoneuroendocrine pathways. As the feeding rates increased, it enhanced the assimilation efficiency in zooplanktons, which in turn, could increase population growth rate.

Among the cladocerans, Ceriodaphnia quadrangula (O. F. Müller) is found in the freshwater ponds and lakes around the world and could be considered as a good replacement for Artemia and rotifer (Sharma \& Chakrabarbarti 2000; Kumar et al., 2000). This species generally found in waters with temperature ranging from 15 to $25{ }^{\circ} \mathrm{C}$ (Rask et al., 1998). 
Although many studies were conducted on effects of different diets, temperature and photoperiod on different cladocerans, especially on Daphnia species (Gophen, 1976; Chinnery \& Williams 2003), little information is available on growth and production of C. quadrangula. In addition, information about mass culture and nutritional values, especially fatty acid content, of $C$. quadrangula under suitable culture conditions and also its application as live food for freshwater fish larvae is not available on literature. Use of this species as live food is very suitable for aquarium or ornamental fish larvae, such as Mayan cichlid, Cichlasoma urophthalmus. This species belongs to the Cichlidae family and has interesting colors, with its eight black bands and its large ocellus on the caudal peduncle, which gives it its scientific name. It is native to the Atlantic slope of tropical Mesoamerica (Central America) and inhabits lakes, rivers, rocky shorelines, lagoons, estuaries, coastal islands and mangroves. It inhabits waters with temperatures from 18 to $34^{\circ} \mathrm{C}$ and salinity from 0 to $40 \mathrm{ppt}$. This species is a dietary generalist, consuming organisms from a variety of disparate taxa, especially crustacean zooplankton.

This paper aims to determine suitable diets and suitable interaction of temperature and photoperiod on growth and production of $C$. quadrangula; mass culture of $C$. quadrangula and its consumption by an ornamental fish, Mayan cichlid (Cichlasoma urophthalmus) larvae.

\section{MATERIALS AND METHODS}

\section{Microalgal Preparation}

Scenedesmus quadricauda, green algae was grown in Bold's basal medium (Nichols \& Bold 1965), at $25.3^{\circ} \mathrm{C}, 12 \mathrm{~h}: 12 \mathrm{~h}$, light:dark cycle and $60 \mu \mathrm{mol}$ photons $\mathrm{m}^{-2} \mathrm{~s}^{-1}$ light intensity in 10-litre carboys with mild continuous aeration for 7 days. The $S$. quadricauda concentration (density) was determined using an improved Neubauer hemocytometer $\left(0.25 \mathrm{~mm}^{2} \times 0.1 \mathrm{~mm}\right)$ under an invert microscope (Ceti Belgium) according to Martinez \& Chakroff (1975) after the samples were fixed in Lugol's iodine solution ( $0.1 \mathrm{ml}$ for $3 \mathrm{ml}$ sample). Algal cells were harvested by centrifugation (Centurion Scientific Ltd, Germany) at 3000 rpm for 10 minutes when the microalgae growth reached the stationary phase. The harvested microalgae were chilled to $4{ }^{\circ} \mathrm{C}$ for one week before starting the main experiment.

\section{Ceriodaphnia quadrangula Stock Preparation}

Ceriodaphnia quadrangula samples were col-

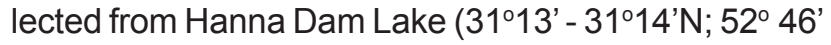
- 52 47' E; Altitude= 2300 m; Area=700 ha; Mean depth $=10 \mathrm{~m}$, Mean annual rainfall $=380 \mathrm{~mm}$ ), located in
Eastern part of Isfahan province, central Iran. Resting eggs (ephippia) of C. quadrangula were easily collected in winter (Jan.-Mar.) from the water surface by sieve number 270 (mesh=0.05 mm) and kept in cool and dry place. Each resting egg contains one egg with 290-520 $\mu \mathrm{m}$ length and each gram of eggs contains $220-260 \times 10^{3}$ eggs. They were identified from other ephippia according Vandekerhkove et al. (2004). To prepare C. quadrangula stocks, eggs were hatched in a $2 \mathrm{~L}$ beaker, stocked at $1 \mathrm{~g} \mathrm{~L}^{-1}$ of filtered and autoclaved EPA ( $96 \mathrm{mg} \mathrm{NaHCO}_{3}, 60 \mathrm{mg} \mathrm{CaSO}, 60 \mathrm{mg}$ $\mathrm{MgSO}_{4}$, and $4 \mathrm{mg} \mathrm{KCl}$ in one liter of distilled water), at $25^{\circ} \mathrm{C}$ and a pH of 7.5 and aerated vigorously. After 5 days, aeration was stopped and hatched nauplii were removed to a new container by siphoning out. Four weeks before starting the main experiment, they were fed with green microalgae, Scenedesmus quadricauda (11.5 $\mu \mathrm{m}$ length, excluding spines, and $5.9 \mu \mathrm{m}$ width). The culture was maintained at the Fishery Research Laboratory at Isfahan University of Technology (FRLIUT). During stocks maintenance, each culture was examined daily, all exuvia and any dead individuals were removed and up to $40 \%$ of water was also changed daily.

\section{Experiment 1- Effects of Different Diets on $C$. quadrangula}

Ceriodaphnia quadrangula were fed with 5 diets including; Scenedesmus quadricauda (S), poultry manure $(P)$, cattle manure $(C)$, mixture of poultry and cattle manures (PC), and mixture of $S$. quadricauda, poultry and cattle manure (SPC) at low and high density (Table 1). This experiment was designed as factorial design of 5 (diet type) $\times 2$ (diet density) with three replicates.

Experiment was run in 30 glass beakers (diameter $=7.5 \mathrm{~cm}$, volume $=250 \mathrm{~mL}$ ) each filled with $200 \mathrm{~mL}$ of filtered autoclaved of culture medium (EPA) and 5 individuals of $C$. quadrangula (from laboratory stock culture). The feeding frequency was twice per day (morning/evening). Aeration was provided at centre of each beaker using tubes with aperture of $5 \mathrm{~mm}$ and also was manually shaken twice a day to ensure homogenous condition inside the beakers. The culture medium (EPA) was changed every three days by passing the $C$. quadrangula culture through $40 \mu \mathrm{m}$ plankton net which was small enough to retain the $C$. quadrangula but large enough to remove most of the detritus, other solid wastes and to prevent bacterial and algal growth on the walls and bottom. Each beaker was examined daily and any dead individuals and uneaten diet were removed. The culture characteristic were $25^{\circ} \mathrm{C}$ temperature, a $12 \mathrm{~h}: 12 \mathrm{~h}$ light:dark cycle and $60 \mu \mathrm{mol}$ photons $\mathrm{m}^{-2} \mathrm{~s}^{-1}$ light intensity. Population growth rate of $C$. quadrangula was studied for a 21-day 
Table 1- Food type, food level and food density used in the experiment 1 ; S. quadricauda in cells $\mathrm{mL}^{-1}$, Poultry manure (35\% C, $15 \% \mathrm{~N}$, $12 \% \mathrm{P})$ in $\mathrm{mg}$ day $^{-1}$, Cattle manure $(25 \% \mathrm{C}, 11 \% \mathrm{~N}, 3 \% \mathrm{~N})$ in $\mathrm{mg} \mathrm{day}^{-1}$, mixed diet with same ratio in weight.

\begin{tabular}{lll}
\hline Food Type & Food level (symbol) & Food density \\
\hline \multirow{2}{*}{ S. quadricauda } & Low (SL) & $1 \times 10^{4}$ \\
& High (SH) & $50 \times 10^{4}$ \\
Poultry manure & Low (PL) & 5 \\
& High (PH) & 10 \\
Cattle manure & Low (CL) & 5 \\
Poultry manure + Cattle & High (CH) & 10 \\
manure & Low (PCL) & $2.5+2.5$ \\
S. quadricauda + Poultry & Low (SPCL) & $5+5$ \\
manure + Cattle manure & High (SPCH) & $0.5 \times 10^{4}+1.25+1.25$ \\
\hline
\end{tabular}

period. Measurements of $C, N$, and $P$ in manures were determined according to APHA (1995).

\section{Experiment 2 - Effects of Temperature and Photoperiod on C. quadrangula}

To examine the effects of temperature $(20,25$, and $\left.30^{\circ} \mathrm{C}\right)$, photoperiod $(24: 0,12: 12,0: 24$, h light: $\mathrm{h}$ dark, L:D), five $C$. quadrangula females were reared in each beaker for a 21-day period. Experiment was run in 27 glass beakers (diameter $=7.5 \mathrm{~cm}$, volume $=250$ $\mathrm{mL}$ ) containing $200 \mathrm{ml}$ of filtered autoclaved culture medium (EPA). All the experiments were performed and maintained inside water baths equipped with fluorescent lamps. This experiment was designed as a factorial of 3 (temperature) $\times 3$ (photoperiod) with three replicates.

Ceriodaphnia quadrangula population was counted under a dissecting microscope using Bogorov's plate chamber. At the end of the experiment 1 and 2, two 10-ml sub-samples from each beaker (6 for each treatment) were removed and all the individuals were counted and fixed with $5 \%$ formalin for length and width measurements (30 individuals for each treatment). The specific growth rate (SGR) of $C$. quadrangula population was calculated using the following formula (James \& Al-Khars 1986):

$$
S G R=\frac{\ln N_{t}-\ln N_{o}}{T}
$$

Where, $T$ is the culture days and $N_{o}$ and $N_{t}$ are the initial and final (highest) density of $C$. quadrangula, respectively. Doubling time $(D t)$ was calculated according to the following formula (James \& Al-Khars 1986):

$$
D_{t}=\frac{L n 2}{S G R}
$$

Experiment 3 - Mass Production of $C$. quadrangula to Rear Mayan Cichlid Larvae Ceriodaphnia quadrangula was cultured for two months in three plastic tanks $(50 \pm 3 \mathrm{~L})$ containing EPA medium with initial density of 30 ind. $\mathrm{L}^{-1}$. Green microalgae, Scenedesmus quadricauda was added at a concentration of $4-6 \times 10^{5}$ cells $\mathrm{mL}^{-1}$ every other day depending on C. quadrangula population size and growth of $S$. quadricauda in the cultures. Care was taken to avoid overfeeding, which was indicated by a cloudy medium or excess precipitation of food. This experiment was maintained at temperature of $25^{\circ} \mathrm{C}$ and continuous light. Aeration was provided at the centre and near the bottom of the tank, using glass tubes having an aperture of $10 \mathrm{~mm}$. C. quadrangula were harvested after 30 days. At each harvest, cultures were passed through plankton nets (mesh size $40 \mu \mathrm{m}$ ) to obtain C. quadrangula individuals. The collected samples were randomly allocated to two sets. One set was washed with distilled water three times and kept in $-40^{\circ} \mathrm{C}$ overnight and then freeze-dried to use for fatty acid analyses. An additional set of $C$. quadrangula was estimated by counting the total number of the population and were processed for feeding of Mayan cichlid larvae. After live harvesting of $C$. quadrangula individuals, ingestion rate of two groups of Mayan cichlid (different in age, size and weight, Table 2) were determined using different densities of $C$. quadrangula. The experiment was carried out with cichlid larvae which were obtained from aquarium shop located in Isfahan, Iran. The cichlid larvae stocks were acclimated to laboratory conditions of filtered autoclaved freshwater, $26 \pm 1^{\circ} \mathrm{C}$ temperature and $12 \mathrm{~h}: 12 \mathrm{~h}$ light : dark for 72 hours and fed on the artificial feed which was used in aquarium shop.

Cichlid larvae were carefully washed in filtered fresh water (Total water hardness $=150 \pm 12 \mathrm{mg} \mathrm{L}^{-1}$ 
Table 2 - Mean ( \pm S.E, $N=10$ ) total length, width, wet weight, and dry weight of cichlid Cichlasoma urophthalmus larvae.

\begin{tabular}{lcccc}
\hline Larvae type & $\begin{array}{c}\text { Length } \\
(\mathbf{m m})\end{array}$ & $\begin{array}{c}\text { Width } \\
(\mathbf{m m})\end{array}$ & $\begin{array}{c}\text { Wet-weight } \\
(\mathbf{m g})\end{array}$ & $\begin{array}{c}\text { Dry-Weight } \\
(\mathbf{m g})\end{array}$ \\
\hline $\begin{array}{l}\text { Early larvae } \\
(5 \text {-weeks-old) }\end{array}$ & $15.8 \pm 1$ & $3.2 \pm 1$ & $110 \pm 10$ & $44.1 \pm 2$ \\
$\begin{array}{l}\text { Advanced larvae } \\
(10 \text {-weeks-old) }\end{array}$ & $25.6 \pm 1$ & $5.5 \pm 1$ & $240 \pm 10$ & $80.1 \pm 5$ \\
\hline \hline
\end{tabular}

as $\mathrm{CaCO}_{3}$ ) and then transferred to beakers $(2 \mathrm{~L})$ with different $C$. quadrangula concentrations of 2,5 and 10 ind. $\mathrm{mL}^{-1}$. The cichlid larvae density in each beaker was 5 larvae $\mathrm{L}^{-1}$. Each beaker was stocked with 10 larvae. Aeration and uniform distribution of $C$. quadrangula was provided. Each feeding treatment was replicated thrice. Three control beakers (without larvae) containing only $C$. quadrangula were used for each concentration. The fish larvae were transferred daily to new containers with the same volume of water and prey density. C. quadrangula counting and the required number for experiment were performed in a zooplankton chamber (Bogorov's plate chamber). The prey density in both control and feeding treatments (with larvae) was measured daily from at least 5 sub-samples. Ingestion rates $\left(I_{R}\right)$ and weight specific ingestion (WSI) of Mayan cichlid larvae were calculated according to Farhadian et al. (2007).

\section{Nutritional Analyses}

For the nutritional analyses, collected samples of $C$. quadrangula and also $S$. quadricauda (collected by centrifugation at $4000 \mathrm{rpm}$ for 5 minutes) were freeze-dried and then protein and lipid contents were determined following the method described by Meyer \& Walther (1988). Fatty acid contents of samples were prepared according to the direct methylation techniques (Divakaran \& Ostrowski 1989).

\section{Statistical Analysis}

Data were analyzed using two-way analysis of variance (ANOVA). Differences in treatment means were compared by Duncan's multiple range tests. The maximum population specific growth rates (SGR) were transformed to Arcsine square root to ensure a normal distribution (Zar, 1984) and tested for statistical significance by two-way ANOVA. All statistical analyses were carried out using statistical package of SPSS (SPSS, version 2002).

\section{RESULTS}

\section{Experiment 1}

The highest mean population density and specific growth rate of Ceriodaphnia quadrangula were obtained with S. quadricauda (3.7 ind. $\mathrm{mL}^{-1}, 0.18$ day $^{-1}$ ) and its mixture with poultry and cattle manure (1.57 ind. $\mathrm{mL}^{-1}, 0.138$ day $^{-1}$ ) at high food level followed by SL and SPCL diet. The poultry manure and its mixture with cattle manure gave a density of $0.66-0.32$ ind. $\mathrm{mL}^{-1}$ and growth rate of $0.095-0.058$ day $^{-1}$, maximum with low food density and minimum with high. Cattle manure solely was not able to support population and growth at both food densities (Fig. 1). Results showed that mean length of $C$. quadrangula varied from 800 to $521 \mu \mathrm{m}$ depend to diet, larger fed on $\mathrm{CL}$ and smaller fed on SH diet (Fig. 2).
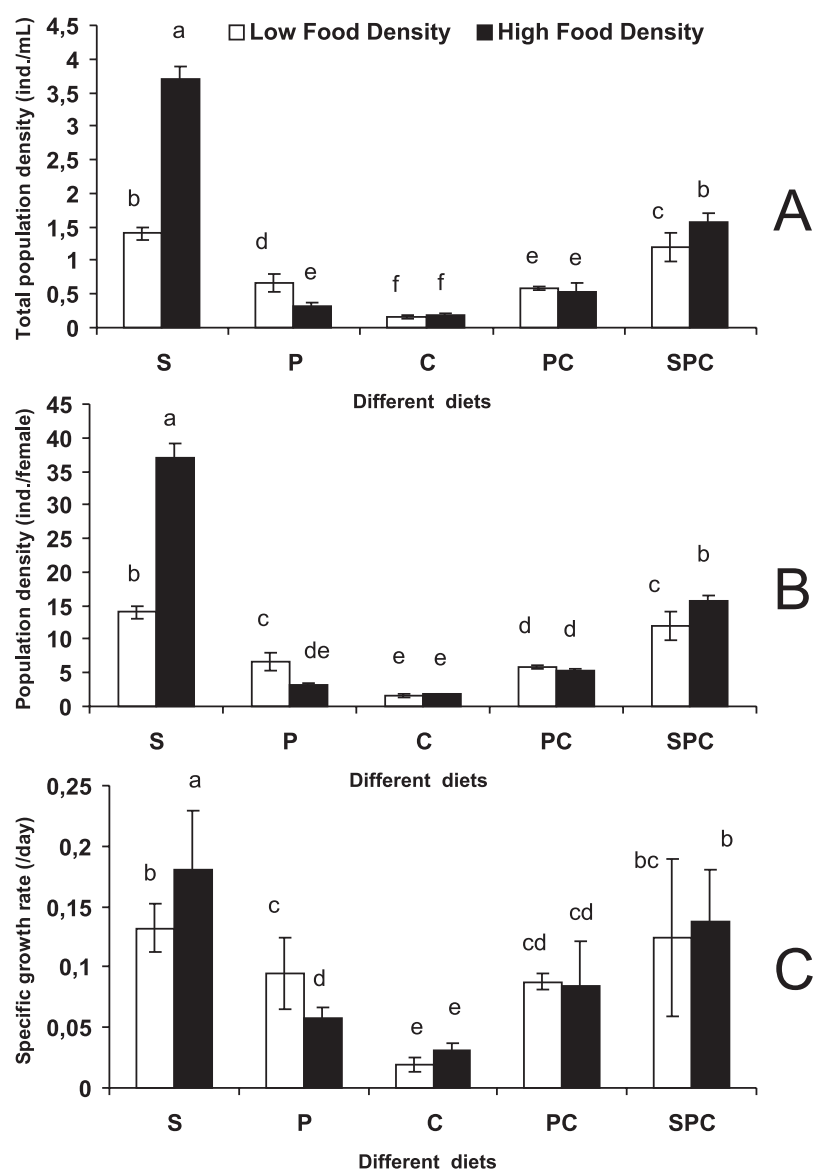

Figure 1 - Mean $\left( \pm S E, N=6\right.$ ) population density (ind. $\left.m L^{-1}\right)(A)$, density (ind./female) (B), and population specific growth rate (SGR) (C) of Ceriodaphnia quadrangula in different diets. Bars in the same letters are not significantly different $(P>0.01)$. 

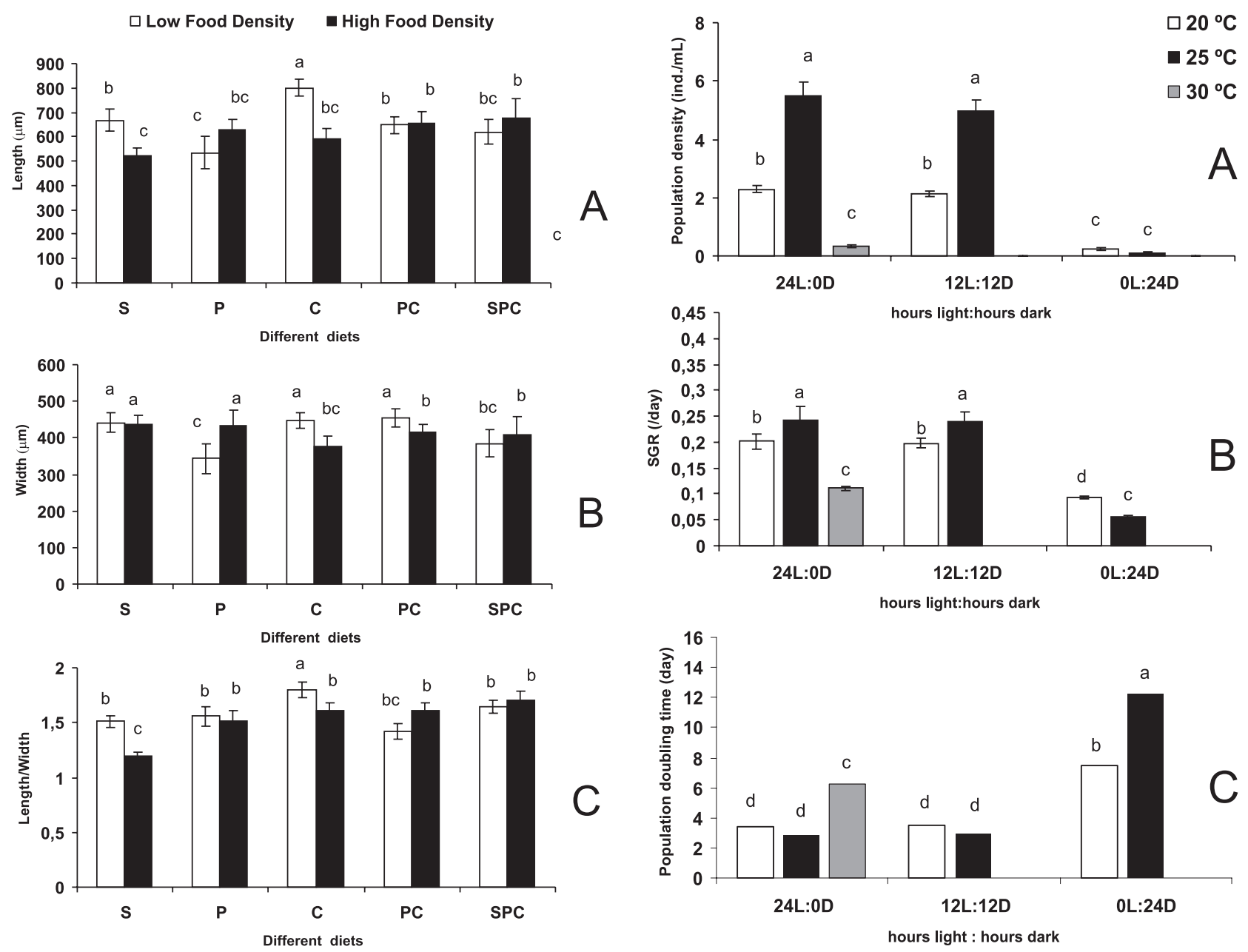

Figure 2 - Mean ( $\pm S E, N=30$ ) body length $(A)$, body width $(B)$, and length / width (C) of Ceriodaphnia quadrangula in different diets. Bars in the same letters are not significantly different $(P>0.01)$.

\section{Experiment 2}

The average population density of $C$. quadrangula ranged from 5.51 to 0.11 ind. $\mathrm{mL}^{-1}$ on the $21^{\text {st }}$ day of culture, the highest at photoperiod of 24: 0 and water temperature of $25^{\circ} \mathrm{C}$, and the lowest at photoperiod of 0:24 (Fig. 3A). The SGR and Dt for C. quadrangula in different photoperiod and temperature levels are shown in Figures 3B and 3C. SGR ranged from -0.03 to $0.24\left(\right.$ day $\left.^{-1}\right)$, the highest at photoperiod of $24: 0$ and a temperature of $25^{\circ} \mathrm{C}$, and the lowest at $0: 24$, and $30^{\circ} \mathrm{C}$.

Female adults of $C$. quadrangula significantly varied in length, width and length to width ratio at treatment interactions (Fig. 4). Results showed that maximum length $(731 \mu \mathrm{m})$ and width $(491 \mu \mathrm{m})$ were obtained at $20^{\circ} \mathrm{C}$ under photoperiods of $12: 12$ and $0: 24$ LD. In contrast, length to width ratio was highest under photoperiod of $24: 0$ and temperatures of 20 and $30^{\circ} \mathrm{C}$.

Figure 3 - Mean $( \pm S E, N=6$ ) population density $(A)$, population specific growth rate (SGR) (B), and population doubling time (C) of Ceriodaphnia quadrangula in different temperature and different photoperiod. Bars in the same letters are not significantly different $(\mathrm{P}>0.01)$.

\section{Experiment 3}

Mass production of $C$. quadrangula in plastic tanks $(50 \mathrm{~L})$ had a density of $2000 \pm 235$ ind. $\mathrm{L}^{-1}$ after 20 day culture fed on S. quadricauda. The protein, lipid and fatty acid profiles of $C$. quadrangula grown on $S$. quadricauda are presented in Table 3. The protein and lipid contents of $C$. quadrangula were $54 \%$ and $12.3 \%$ dry weight, respectively. Monounsaturated fatty acids (MUFAs) constituted the major part of the fatty acids (36.91\%) followed by saturated fatty acids (SFAs) $(27.03 \%)$ and polyunsaturated fatty acids (PUFAs) (26.74\%). The major SFAs, MUFAs, and PUFAs for C. quadrangula were C16:0 (14.5\%), C16:1n-7 plus C18:1n-9 (12.2 and $12.8 \%)$ and C18: 2n-6 (16.4\%), respectively. In general, the suitable $n-3 / n-6$ of $0.57: 1$ for C. quadrangula makes it as more suitable and nutritious prey for fish larvae.

Ingestion rates increased continuously with the increase in prey density and cichlid larval size. 
Table 3 - Mean ( \pm SE, N=3) protein, lipid and fatty acid composition ( $\%$ total fatty acid) of Scenedesmus quadricauda and Ceriodaphnia quadrangula.

\begin{tabular}{lll}
\hline Fatty acids & S. quadricauda & C. quadrangula \\
\hline Protein $(\% \mathrm{DW})$ & $43.5 \pm 2.23$ & $54 \pm 3.27$ \\
Lipid $(\% \mathrm{DW})$ & $9.23 \pm 1.10$ & $12.30 \pm 1.10$ \\
C14:0 & $1.50 \pm 0.20$ & $3.21 \pm 0.12$ \\
C14:1n-5 & - & $0.52 \pm 0.15$ \\
C16:0 & $9.45 \pm 1.30$ & $14.5 \pm 1.50$ \\
C16:1n-7 & $0.75 \pm 0.22$ & $12.20 \pm 1.32$ \\
C17:0 & - & $2.05 \pm 0.05$ \\
C17:1n-7 & - & $1.62 \pm 0.05$ \\
C18:0 & $0.65 \pm 0.15$ & $5.52 \pm 0.30$ \\
C18:1n-9 & $3.20 \pm 0.40$ & $12.85 \pm 0.65$ \\
C18:1n-7 & $0.45 \pm 0.05$ & $9.52 \pm 0.40$ \\
C18:2n-6 & $7.45 \pm 1.25$ & $16.41 \pm 0.56$ \\
C18:3n-3 & $25.61 \pm 4.60$ & $4.21 \pm 0.05$ \\
C20:0 & - & $0.80 \pm 0.07$ \\
C20:1n-9 & $0.35 \pm 0.07$ & $0.20 \pm 0.03$ \\
C20:4n-6 & - & $0.65 \pm 0.01$ \\
C:20:3n-3 & - & $0.51 \pm 0.01$ \\
C:20:4n-3 & - & $0.45 \pm 0.03$ \\
C20:5n-3 & - & $3.23 \pm 0.35$ \\
C22:0 & - & $0.53 \pm 0.05$ \\
C22:6n-3 & - & $1.28 \pm 0.19$ \\
C24:0 & - & $0.42 \pm 0.03$ \\
Total SFAs & 11.60 & 27.03 \\
Total MUFAs & 4.75 & 36.91 \\
Total PUFAs & 33.06 & 26.74 \\
Total $n-3$ & 25.61 & 9.68 \\
Total $n-6$ & 7.45 & 17.06 \\
n-3: $n-6$ & $3.44: 1$ & $0.57: 1$ \\
\hline \hline
\end{tabular}

Results showed that early cichlid fish larvae consumed C. quadrangula at 220-584 ind. day ${ }^{-1}$. Similarly, advance cichlid fish larvae ingested $C$. quadrangula at 528-1956 ind. day ${ }^{-1}$. This study indicated that cichlid larvae, at early and advanced stages, can ingest $C$. quadrangula. The WSI significantly increased with increasing prey density $(p<0.05$, Fig. 5$)$. The WSI values ranged from 2.99 to $7.95 \%$ for while for early fish larvae, these values ranged from 3.95 to $14.62 \%$ for advance larvae per day at different food concentrations (Fig. 5). The larvae dry weights in each larval group were significantly higher at 10 ind. $\mathrm{mL}^{-1}$ than 2 and 5 ind. $\mathrm{mL}^{-1}$ (Table 4 ). The maximum survival rate and dry weight were observed at 10-week larvae at prey density of 10 ind. $\mathrm{mL}^{-1}$.

\section{DISCUSSION}

\section{Suitable Diets for C. quadrangula}

Ceriodaphnia quadrangula population grew significantly $(p<0.05)$ higher in S and SPC than in $P, C$ and PC (Fig.1). Comparison between different manure diets $(P, C$ and $P C)$ showed that $P$ diet gave better performance in terms of population and growth on $C$. quadrangula, especially at low manure density. In this study, mean population density at different examined diets ranged between 0.15 and 3.70 ind. $\mathrm{mL}^{-1}$ (1503,700 ind. $\mathrm{L}^{-1}$ ). Our results could support the findings of previous studies on Ceriodaphnia cornuta Sars (733-1,930 ind. $\mathrm{L}^{-1}$ ) using organic manures (Srivastava et al., 2006), on C. cornuta (50-10,232 ind. $\left.\mathrm{L}^{-1}\right)$ using chicken manure (Altaff \& War, 2010), on Moina mongolica Daday (540-3,500 ind. $\left.\mathrm{L}^{-1}\right)$ using green algae Nananochloropsis oculata Droop (He et al., 2001). 
In fact, the numerical differences could be attributed to inoculum and residual densities of cultured organisms (Malhotra \& Langer, 2010) because the optimum space requirement for each species may be different. The increasing population density of $C$. quadrangula with algal concentration is common in laboratory experiments (Nandini \& Rao 1998). Nandini \& Sarma (2003) stated density of cladocerans under the highest algal food level varied from 2,300 to 71,000 ind. $\mathrm{L}^{-1}$. They reported that Chlorella at a density of $0.8 \times 10^{6}$ cells $\mathrm{mL}^{-1}$ gave better growth for cladoceran species. The lower density of $C$. quadrangula fed on $S$. quadricauda could be described by spine cells in S. quadricauda compared to spineless cells such as Chlorella (Fileto et al., 2004). Generally, size, shape, spines, colonies, filaments, hard cell walls and gelatinous sheaths, and movements of microalgae
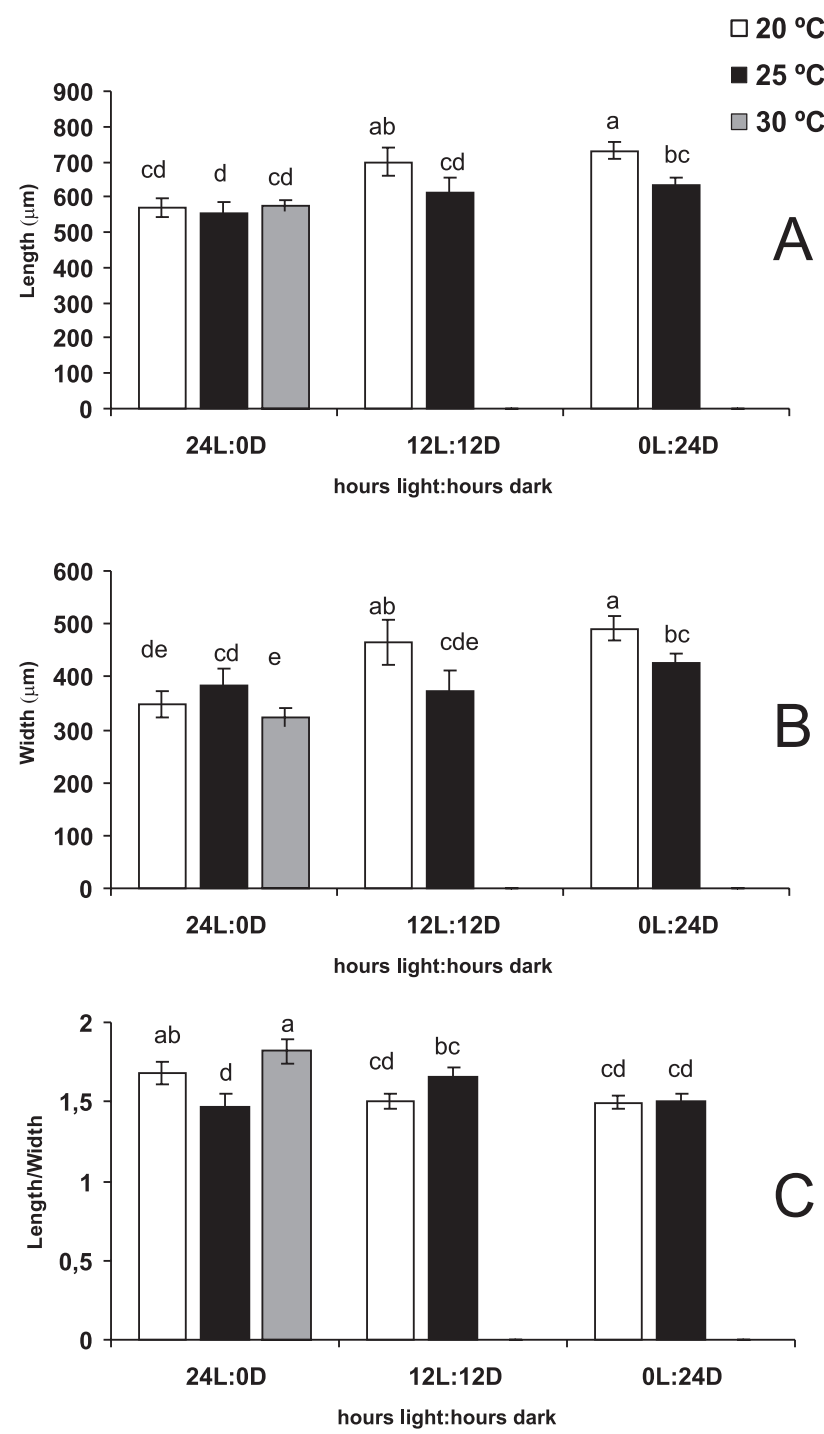

Figure 4 - Mean $( \pm S E, N=30$ ) body length $(A)$, body width $(B)$, and length / width $(C)$ of Ceriodaphnia quadrangula in different temperatures and different photoperiods. Bars in the same letters are not significantly different $(P>0.01)$. affect on feeding activities in cladocerans (Fileto et al., 2004). Although most of cladocerans filter organic manures, the size of particle and filtering efficiency are depend on their setae appendage morphology (He et al., 2001). In this study, lower performance of manure diets, especially at high concentration, may be due to low quality, lower filtration rate and aggregation of manure particles. Therefore, better growth and production in low concentration of manures could be attributed to a good adaptation of $C$. quadrangula as reported by Stemberger \& Gilbert (1985). Therefore, poultry manure can be used as diet for mass culture of cladoceran, C. quadrangula as well as a suitable replacement for microalgae such as $S$. quadricauda.

\section{Suitable Interactions of Temperature and Photoperiod for C. quadrangula}

Ceriodaphnia quadrangula grew at interactions of $20^{\circ} \mathrm{C}$ and $25^{\circ} \mathrm{C}$ with photoperiod of $24: 0$ (hL:hD) and 12:12. Contrarily, this species did not grow well at interactions of 0:24 with three levels of temperatures. As indicated by other researchers, water temperature strongly affects growth and reproduction in cladoceran cultures (Benider et al., 2002; Ovie \& Edborge, 2002; Rose et al., 2002). The possible reason for the lower growth and production levels at higher temperatures (e.g., $30{ }^{\circ} \mathrm{C}$ in this study) could be related to higher energy requirements resulting from increasing respira-

$\square$ Early larvae(110 mg) $\square$ Advanced larvae (240 mg)
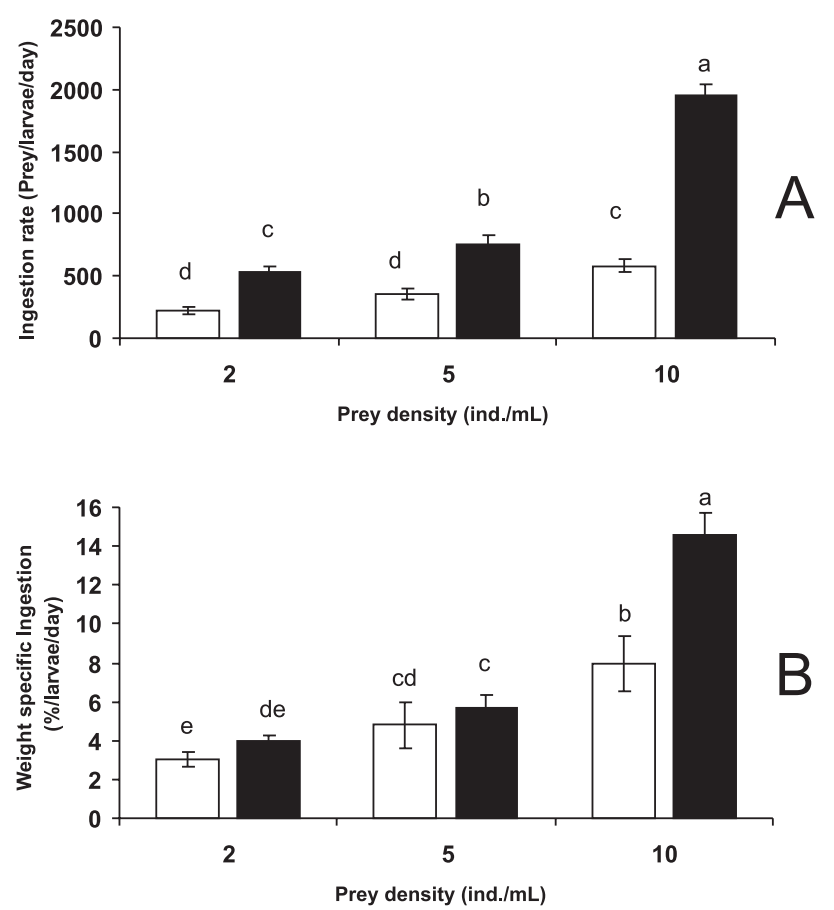

Figure 5 - Mean $( \pm S E, N=3)$ ingestion rates $(A)$ and weight specific ingestion (WSI) (B) of Mayan cichlid larvae fed on different Ceriodaphnia quadrangula density. Bars in the same letters are not significantly different $(P>0.01)$. 
Table 4 - Dry weight (mg larvae ${ }^{-1}$ ) and survival rate (\%) of cichlid Cichlasoma urophthalmus larvae fed on Ceriodaphnia quadrangula in 10 days period at three prey densities (ind. $\mathrm{mL}-1$ ). Values are mean \pm standard error from three replications. Values within each row do not share the same superscript are significantly different $(P<0.05)$.

\begin{tabular}{|c|c|c|c|c|c|c|}
\hline & \multicolumn{3}{|c|}{ 5-weeks-old larvae } & \multicolumn{3}{|c|}{ 10-weeks-old larvae } \\
\hline Prey density & 2 & 5 & 10 & 2 & 5 & 10 \\
\hline Dry-weight & $\begin{array}{l}48.3^{\dagger} \\
\pm 0.5\end{array}$ & $\begin{array}{l}52.6^{\mathrm{e}} \\
\pm 1.3\end{array}$ & $\begin{array}{l}57.6^{\mathrm{d}} \\
\pm 2.1\end{array}$ & $\begin{array}{l}87.8^{c} \\
\pm 3.2\end{array}$ & $\begin{array}{l}90.2^{b} \\
\pm 2.5\end{array}$ & $\begin{array}{l}97.1^{\mathrm{a}} \\
\pm 4.2^{2}\end{array}$ \\
\hline Survival rate & $\begin{array}{l}80.3^{\mathrm{e}} \\
\pm 3.3^{2}\end{array}$ & $\begin{array}{l}90.3^{c} \\
\pm 3.3\end{array}$ & $\begin{array}{c}96.6^{\mathrm{b}} \\
\pm 3.3\end{array}$ & $\begin{array}{l}86.6^{d} \\
\pm 6.6\end{array}$ & $100^{a}$ & $100^{a}$ \\
\hline
\end{tabular}

tion and feeding rates at higher temperatures (Gophen, 1976).

In this study, the maximum mean specific growth rate (SGR) for $\mathrm{C}$. quadrangula at $25^{\circ} \mathrm{C}$ was significantly higher than that at $20^{\circ} \mathrm{C}$ and $30^{\circ} \mathrm{C}$. According to Nandini \& Sarma (2003), cladocerans have SGR values ranging from 0.01 to 1.50 day $^{-1}$ depending on the species, food type and density, and temperature (Nandini \& Sarma, 2000; 2002). Higher SGR values in the current study, compared to other cladocerans such as Simocephalus and Daphnia, could be attributed to their shorter lifespan and higher fecundity (Stearns, 1976), shorter maturation times, ripening of gametes and their release, and continuous breeding of females in these conditions.

Findings of this study showed that the mean total production of $C$. quadrangula at interaction $20^{\circ} \mathrm{C}, 25$ ${ }^{\circ} \mathrm{C}$ and $30^{\circ} \mathrm{C}$ with photoperiod of $24: 0$ were $2.28,5.51$, and 0.34 ind. $\mathrm{mL}^{-1}$, respectively. These production levels were slightly lower compared to levels obtained for other species of freshwater cladocerans as recorded by Nandini \& Sarma (2003) at interaction $25^{\circ} \mathrm{C}$ and 12:12 LD. The differences could mostly be attributed to species, food type and density, initial culture density and culture volume.

In this study we found smaller sizes in $C$. quadrangula reared under 24:0 LD in all three levels of temperature. This could be due to higher molting rate and higher reproduction. Furthermore, smaller adult sizes of $C$. quadrangula may be related to size of the ingested microalgae. Since C. quadrangula ingested smaller sizes of $S$. quadicauda under continuous light, thus they had smaller sizes compared to other treatments (DeMott, 1985; Kobayashi, 1991).

\section{Nutritional Values of C. quadrangula}

In this study, the protein and lipid contents of C. quadrangula were $54 \%$ and $12.3 \%$ dry weight, respectively. These amounts meet a major part of nutritional requirements of fish larvae. The differences in protein and lipid content are varied depend on species, age of individuals, physiological conditions, food and temperature.
As shown in Table 3, in the fatty acid profile of C. quadrangula, 27.3 and $63.7 \%$ of saturated and unsaturated fatty acids were determined, respectively. C. quadrangula grown on S. quadricauda contained higher amounts of 18-carbon unsaturated fatty acids such as linoleic acid (18:2n-6), linolenic acid (18:3n$3)$, oleic acid (18:1n-9), vaccenic acid (18:1n-7) than 20-carbon unsaturated fatty acids which are useful for freshwater fish larvae and fry (Oka et al., 1982). Palmetic acid (16:0), palmitoleic acid (16:1n-7), myristic acid (14:0) and stearic acid (18:0) were higher than other saturated fatty acids.

Watanabe (1987) stated that freshwater species required mainly $18: 2 n-6$ or $18: 3 n-3$ or both as essential fatty acids and increase growth and survival in fish larvae. Lower content of HUFAs detected in C. quadrangula may be attributed to low efficiency of delta- 5 and delta- 6 desaturaes as reported by Bec et al. (2003) for Daphnidae Simocephalus vetulus. Another reason for lower fatty acid content of $C$. quadrangula can be associated with lower filtration and assimilation of $S$. quadicauda due to its unsuitable morphological (such as presence of horns in the apical cells) as well as unbalance biochemical properties. For example, Brett et al. (2006) reported that the differences in n-3 to n-6 fatty acids in Daphnia were strongly dependent on diet. In general, C. quadrangula has suitable fatty acid content, which made it as good live prey for fish larvae. In general, aquatic animals can synthesize saturated fatty acids and lower unsaturated fatty acids to PUFAs (Halver, 1980). The 20-carbon chained PUFAs are essential for proper development of fish larvae and fry (Oka et al., 1982), and these were accumulated in $C$. quadrangula (Table 3).

\section{Rearing of Mayan Cichlid (Cichlasoma urophthalmus) Larvae}

In this study, cichlid larvae ingested $C$. quadrangula in both larval sizes (Table 2, Fig. 5) due to its suitable body size and absence of spine in the caudal parts. Some species of zooplankton are not consumed by fish larvae due to spines in body (Zaret, 1980). Comparing results between 5-weeks-old and 
10-weeks-old larvae showed that ingestion rate forthe latter were increased. These differences could be related to improvement of prey capture and handling skills of 10-weeks-old cichlid larvae, therefore they consume higher numbers with increasing prey density (Alanis et al., 2009).

\section{CONCLUSION}

As conclusion, C. quadrangula had better growth and reproduction on $\mathrm{S}$ and $\mathrm{P}$ diets, and interactions of $20^{\circ} \mathrm{C}$ and $25^{\circ} \mathrm{C}$ with $24: 0$ and $12: 12, \mathrm{~L}: \mathrm{D}$, its suitable body size (521-800 $\mu \mathrm{m}$ in length), its fatty acid content (PUFAs $=26.74 \%$ total fatty acid, $n-3: n-6=0.57: 1$ ), its consumption by cichlid larvae (220-1956 ind. day ${ }^{-1}$ larvae $^{-1}$ ), suitable larval growth and survival rate make it as a live food to use in aquaculture industry.

\section{ACKNOWLEDGMENTS}

Authors are grateful to Isfahan University of Technology (IUT), Isfahan, Iran to support this study.

\section{REFERENCES}

Alanis, J.G.; Sarma, S.S.S. \& Nandini, S. 2009. Prey selectivity and functional response by larval red-eyed tetra Moenkhausia sanctaefilomenae (Steindachner, 1907) (Characiformes: Characidae). Braz. Arch. Biol. Techn. 52: 1209-1216.

Altaff, K. \& War, M.U.D. 2010. Culture of Ceriodaphnia cornuta, using chicken manure as fertilizer: conversion of waste product into highly nutritive animal protein. Pak. J. Sci. Ind. Res. 53: 89-91.

Alva-Martinez, A.F.; Sarma, S.S.S. \& Nandini, S. 2004. Population growth of Daphnia pulex (Cladocera) on a mixed diet (Microcystis aeruginosa with Chlorella or Secenedesmus. Crustaceana. 77: 973-988.

APHA. 1995. Standard methods for examination of water and wastewater, $19^{\text {th }}$ edition, American Public Health Association, DC.

Bec, A.; Desvilettes, C.; Vera, A.; Fontvielle, D. \& Bourdier G. 2003. Nutritional value of different food sources for the benthic Daphnidae Simocephalus vetulus: role of fatty acids. Arch. Hydrobiol. 156: 145-163.

Benider, A.; Tifnouti, A. \& Pourriot, R. 2002. Growth of Moina macrocopa (Straus 1820) (Crustacea, Cladocera): influence of trophic conditions, population density and temperature. Hydrobiologia 468: 1-11.
Boersma, M. \& Vijverberg, J. 1996. Food effects on life history traits and seasonal dynamics of Ceriodaphnia pulchella. Freshwater. Biol. 35: 25-34.

Brett, M.T.; Muller-Narvarra, D.C.; Ballantyne, A.P.; Ravet J.L. \& Goldman C.R. 2006. Daphnia fatty acid composition reflects that of their diet. Limnol. \& Oceanogr. 51: 2428-2437.

Buikema, A.L. 1973. Some effects of light on the growth, molting, reproduction and survival of the cladoceran, Duphnia pulex. Hydrobiologia 41: 391-418.

Chinnery, F.E.\& Williams, J.A. 2003. Photoperiod and temperature regulation of diapause egg production in Acartia bifilosa from Southampton Water. Mar. Ecol- Prog. Ser. 263: 149-157.

DeMott, W.R. 1985. Relations between filter meshsize, feeding mode, and capture efficiency for cladocerans feeding on ultrafine particles. Ergeb Limnol. 21: 125-134.

Divakaran, S. \& Ostrowski, A. C. 1989. Fatty acid analysi,s of fish eggs without solvent extraction. Aquaculture 80: 371-37.

Domínguez-Domínguez, O.; Nandini, S. \& Sarma, S.S.S. 2002.Larval feeding behaviour of the endangered fish golden bubblebee goodeid, Allotoca dugesi (Bean) (Goodeidae) offered zooplankton: implications for conservation. Fisheries Manag. Ecol. 9: 285-291.

Farhadian, O.; Yusoff, F.M. \& Arshad, A. 2007. Ingestion rate of postlarvae Penaeus monodon fed Apocyclops dengizicus and Artemia. Aquaculture 269: 265-270.

Filito, C.; Arcifa, M.S.; Ferrao-Filho, A.S. \& Silva, L.H.S. 2004. Influence of phytoplankton fractions on growth and reproduction of tropical cladocerans. Aquat. Ecol. 38: 503-514.

Gophen, M. 1976. Temperature dependence of food intake, ammonia excretion and respiration in Ceriodaphnia reticulata (Jurine) (Lake Kinneret). Freshwater Biol. 6: 451-455.

Halver, J.E. 1980. Lipids and fatty acids. In: Pillay; T.V.R. (Ed.). Fish Feed and Technology, Aquaculture Development and Coordination Programme. ADCP/ REP/ 80/11, FAO/ UNDP Training Course in Fish Feed Technology, College of Fisheries, Washington, Seattle, 9 Oct.- 15 Dec. 1978. UNDP, FAO, Rome, Italy, $434 \mathrm{pp}$.

He, Z.H.; Qin, J.G.; Wang, Y.; Jiang, H. \& Weng Z. 2001. Biology of Moina mongolica (Moinidae, Cladocera) and perspective as live food for marine fish larvae: review. Hydrobiologia 457: 25-37.

James, C.M. \& Al-Khars, A.M. 1986. Studies on the production of planktonic copepods for aquaculture. Syllogeus 58: 333-340. 
Jansson, B.O. \& Källander, C. 1984. On the diurnal activity of some littoral peracarid crustaceans in the Baltic Sea. J. Exp. Mar. Biol. Ecol. 2: 24-36.

Khadka, R.B. \& Rao, T.R. 1986. Prey selection by common carp (Cyprinus carpio var. Communis) larvae in relation to age and prey density. Aquaculture 88: 69-74.

Kobayashi, T. 1991. Body lengths and maximum gut food particles sizes of dominant cladocerans and calanoid copepods in Wallerawang reservoir, New South Wales. Aust. J. Mar. Freshwat. Res. 42: 399-408.

Kumar, S.; Srivastava, A. \& Chakrabarti, R. 2005. Study of digestive proteinases and proteinase inhibitors of Daphnia carinata. Aquaculture 243: 367-372.

Kumar, S.; Sharma, J.G. \& Chakrabarti, R. 2000. Quantitative estimation of proteolytic enzyme and ultrastructural study of anterior part of intestine of Indian major carp (Catla catla) larvae during ontogenesis. Curr. Sci. 79: 1007-1011.

Malhotra, Y.R. \& Langer, S. 2010. Nutritional and density-dependent responses of some Cladocera. Aquac. Res. 24: 631-640.

Martinez, M.P. \& Chakroff, J.B.P. 1975. Direct phytoplankton counting technique using the hemacytometer. Philipp. Agric. Sci. 59: 43-50.

Meyer, E. \& Walther, A. 1988. Methods for estimation of protein, lipid, 529 carbohydrates and chitin levels in freshwater invertebrates. Arch. Hydrobiol. 113: 161-177.

Miliou, H. 1992. Effects of light (photoperiod, spectral composition) on the population dynamics of Tisbe holothuriae Humes (Copepoda: Harpacticoida). Hydrobiologia 232: 201-209.

Mobley, C.T. 1987. Time-series ingestion rate estimates on individual Calanus pacificus Brodsky: Interactions with environmental and biological factors. J. Exp. Mar. Biol. Ecol. 114: 199-216.

Nandini, S. \& Sarma, S. S. S. 2000. Life table demography of four cladoceran species in relation to algal food (Chlorella vulgaris) density. Hydrobiologia 435: 117-126.

Nandini, S. \& Sarma, S.S.S. 2002. Competition between Moina macrocopa and Ceriodaphnia dubia: a life table demography study. Hydrobiologia 87: 85-95.

Nandini, S. \& Sarma, S.S.S. 2003. Population growth of some genera of cladocerans in relation to algal food (Chlorella vulgaris) levels. Hydrobiologia 491: 211-219.

Nichols, H.W. \& Bold, H.C. 1965. Trichorsarcina polymorpha gen. et sp. nov. J. Phycol. 1: 34-38.

Oka, A.; Suzuki, N. \& Watanabe, T. 1982. Effect of fatty acids in Moina on the fatty acid composition larvae Ayu Plecoglossus altivelis. B. Jpn. Soc. Sci. Fish. 48: 1159-1162.

Ovie, S.I. \& Egborge, A.B.M. 2002. The effect of different algal densities of Scenedesmus acuminatus on the population growth Moina micrura Kurz (Crustacea: Anomapoda, Moinidae). Hydrobiologia 477: 41-45.

Rask, M.; Nyberg, K.; Markkanen, S. \& Ojala, A. 1998. Forestry in catchments: effects on water quality, plankton, zoobenthos and fish in small lakes. Boreal Environ. Res. 3: 75-86.

Rose, R.M.; Warne, M.S.J. \& Lim, R.L. 2002. Some life history responses of the cladoceran Ceriodaphnia cf. dubia to variations in population density at two different food concentrations. Hydrobiologia 481: 157-164.

Sarma, S.S.S. 1991. Rotifers and aquaculture (Review). Environ. \& Ecol. 9: 414-428.

Sarma, S.S.S. \& Rao, T. R. 1991. The combined effects of food and temperature on the life history parameters of Brachionus patulus Muller (Rotifera). Int. Rev. Hydrobiol. 76: 225-239.

Segal, E. 1970. Light: Animals: Invertebrates. In: Kinne, O. (ed.) Marine Ecology; Vol. I, New York; Wiley-Interscience. 159-211 pp.

Sharma, J.G. \& Chakrabarti, R. 2000. Replacement of live-food with refrigerated- plankton food for Cyprinus carpio (L.) larvae cultured with three different types of biological filters. Curr. Sci. 79: 214-219.

SPSS. 2002. Statistical package for social science, version 11.5, SPSS Inc., Michigan Avenue, Chicago, Illinois, USA.

Srivastava, A.; Rathore, R.M. \& Chakrabarti, R. 2006. Effects of four different doses of organic manures in the production of Ceriodaphnia cornuta. Bioresource Technol. 97: 1036-1040.

Stearns, S.C. 1976. Life history tactics: a review of ideas. Q. Rev. Biol. 51: 3-47.

Stemberger, R.S. \& Gilbert, J.J. 1985. Body size, food concentration and population growth in planktonic rotifers. Ecology 66: 1151-1159.

Vandekerhkove, J.; Declerck, S.; Vanhove, M.; Brendonck, L.; Jeppesen, E.; Conde Porcuna, J. M. \& De Meester, L. 2004. Use of ephippial morphology to assess richness of anomopods: potentials and pitfalls. J. Limnol. 63: 75-84.

Watanabe, T. 1987. The use of Artemia in fish and crustacean farming in Japan. In: Sorgeloos, P.; Bengtson, A.; Decleir, W. \& Jaspers, E. (eds.). Artemia Research and its Applications. Volume 3, Ecology, Culture, Use in Aquaculture. Universa Press, Wetteren, Belgium. 372-393 pp. 
Braz. J. Aquat. Sci. Technol., 2012, 16(2):1-11.

Zar, J.H. 1984. Bioststistical analysis, 2nd edition. Prentice Hall Inc., Englewood Cliffs, New York, USA.

Zaret, T.M. 1980. Predation and freshwater communities. Yale University Press, New Haven, USA.

Submetido: Julho/2011

Revisado: Novembro/2011

Aceito: Março/2012 